\title{
Earliest Results in the Use of Activated Composite Membranes for the Transport of Silver Ions from Aqueous Solutions
}

\author{
Yucundo Mendoza-Tolentino, ${ }^{1}$ Carlos Andrés Galán-Vidal, ${ }^{1}$ \\ Giaan Arturo Álvarez-Romero, ${ }^{1}$ M. T. Ramírez-Silva, ${ }^{2}$ and Ma. Elena Páez-Hernández ${ }^{1}$ \\ ${ }^{1}$ Laboratorio 2, Área Académica de Química, Universidad Autónoma del Estado de Hidalgo, \\ 42184 Mineral de la Reforma, HGO, Mexico \\ ${ }^{2}$ Laboratorio R-105, Área de Química Analítica, Universidad Autónoma Metropolitana-Iztapalapa, 09340 México, DF, Mexico
}

Correspondence should be addressed to Ma. Elena Páez-Hernández; mpaezh@gmail.com

Received 1 September 2014; Accepted 22 October 2014; Published 17 November 2014

Academic Editor: Eri Yoshida

Copyright (C) 2014 Yucundo Mendoza-Tolentino et al. This is an open access article distributed under the Creative Commons Attribution License, which permits unrestricted use, distribution, and reproduction in any medium, provided the original work is properly cited.

\begin{abstract}
This paper presents the results concerning the first use of activated composite membranes (ACMs) for the facilitated transport of silver ions containing di-(2-ethylhexyl)-dithiophosphoric acid (DTPA) as the carrier. DTPA was immobilized by interfacial polymerization in a dense layer that was deposited in a porous layer, which was prepared on a nonwoven fabric support by phase inversion. The influence of fundamental parameters affecting the transport of silver ion as the carrier concentration in the membrane phase and stripping agent variation of the stripping solution have been studied. In the optimal conditions, the amount of silver transported across the ACMs was greater than 50\%, whereas if the content of the carrier is modified, more than the $90 \%$ of the initial silver is removed from the feed phase.
\end{abstract}

\section{Introduction}

Separation processes are essential to the chemical, petroleum refining, and materials processing industries. These are defined as processes using physical, chemical, or electrical forces to isolate selected constituents from a mixture. The functions of separation processes include the removal of impurities from raw materials, products, and by-products as well as the separation of recycle streams and the removal of contaminants from air and water waste streams. The traditional chemical engineering methods of separation and purification include distillation, crystallization, adsorption, extraction, and membrane processes [1].

Liquid membranes (LMs), which are based on solvent extraction technology, have been proposed as a method of separation, representing an attractive alternative for the separation and recovery of chemical compounds. Liquid membranes may contain chemical carriers to facilitate the selective transport of gases or ions. Thus, the carrier reacts with one of the components of the source solution (feed) helping to transport it across the membrane [2]. Liquid membranes have been suggested as a clean technology due to characteristics such as high specificity and productivity as well as low emissions and energy utilization [3]. In recent years, several researchers have worked intensively on the application of liquid membranes for the recovery or separation of metal ions from aqueous solutions [4]. An example of this is the use of LM in extraction of contaminants metal ions such as cadmium, chromium, and lead $[5,6]$. In the hollow fiber configuration [7], the LMs have been used to extract copper and cobalt from wastewater, and, recently, ionic liquids have been incorporated as carriers liquid membranes for the selective separation of zinc, cadmium, iron, and copper [8].

However, despite these advantages, it is well known that LMs are not widely used on an industrial scale, mainly due to their poor stability and subsequently short lifetime [9, 10]. Some factors that contribute to these disadvantages are the evaporation of the solvent used to prepare the liquid membrane, the solubility of the liquid membrane components, or its emulsification in the adjacent aqueous phases. In the supported liquid membrane configuration (SLM), 
membrane pores of the polymeric porous support became more elliptical and dilated which facilitate the loss of carrier from the membrane phase affecting in a significant way the transport process $[11,12]$. For these reasons, different approaches to improving LMs stability have been suggested. Thus, an increase of the LM stability with the decrease of the polarity of the solvent used as receiving phase has been demonstrated [13]. Furthermore, stabilization of LM supported in a polymeric support (SLM) has been tried with plasma polymerization surface coating and the formation of barrier layers on membrane surfaces, either by physical deposition or by interfacial polymerization [14-17]. However, the use of a coating to recover the LM may significantly reduce the flux of ions across the membrane $[18,19]$.

A promising alternative to the transport of ions is the use of the activated composite membranes (ACMs) which immobilize the carrier in one of the polymeric layers that constitute them. Studies completed with these types of membranes have shown ACM to have a higher stability than LM with comparable metal ion permeation, while maintaining all the advantages belonging to LM [21,22]. Nevertheless, despite having been used for the transport and separation of a variety of metal ions, their effectiveness has not been tested in the extraction and transport of silver ions.

Thus, this paper has proposed the use of activated composite membranes (ACMs) in the transport of silver due to the importance of silver in many industrial applications and because the silver content in samples of environmental interest is increasing due to the use of its components and preparations in industry and medicine. Therefore, their separation and recovery from industrial effluents is of great interest [23-25]. Parameters such as the concentration of carrier agent [di-(2-ethylhexyl)dithiophosphoric acid (DTPA)] in the membrane and the nature of the receptor phase were studied to achieve the maximum silver flow through the ACM.

\section{Materials and Methods}

2.1. ACM Preparation. The ACMs were prepared as described in the literature [21]. First, to form the porous layer, a polysulfone casting solution was prepared by dissolving the polymer $(15 \%, \mathrm{w} / \mathrm{w})$ in N,N-dimethyl formamide (DMF) by vigorous stirring for $12 \mathrm{~h}$. Then, deposition of a polysulfone solution onto the nonwoven paper support (Hollytex 3329, Talas Co., NY, USA) was performed. The coated support was immersed in a water bath at room temperature to induce phase inversion, whereupon the prepared porous layer was introduced into the oven during $60 \mathrm{~min}$ at $55^{\circ} \mathrm{C}$ to dry. As a second step, a dense layer containing the carrier was formed on the obtained porous layer by interfacial polymerization as follows: the porous layer was impregnated with an aqueous diamine solution (1,3-phenylene diamine in deionized water containing sodium dodecyl sulfate as an aqueous stabilizing agent) and subsequently with an organic solution (1,3,5benzene-tricarbonyl chloride and the desired concentration of the DTPA in kerosene). The excess of the solution was washed off the membrane surface with distilled water and finally the membrane was dried in an oven during $60 \mathrm{~min}$ at $55^{\circ} \mathrm{C}$. A blank composite membrane (BCM) was also prepared by following the same procedure without including the carrier (DTPA). Both ACM and BCM were cut into circles to fit an $11.32 \mathrm{~cm}^{2}$ area.

2.2. Silver Transport Experiments. The cell used for transport experiments has two compartments $[26,27]$ : one for the feed solution (source) consisting of silver nitrate $4.6 \times 10^{-4} \mathrm{~mol} \mathrm{~L}^{-1}$ in $\mathrm{HNO}_{3} 0.1 \mathrm{~mol} \mathrm{~L}^{-1}$, and the other for the receiving solution (stripping) containing a complexing silver agent in sulfuric acid $2 \mathrm{~mol} \mathrm{~L}^{-1}$. Both compartments have a capacity of $200 \mathrm{~mL}$ and are separated by an orifice of $11.32 \mathrm{~cm}^{2}$ where the prepared ACM is placed. All transport experiments were carried out in triplicate at room temperature. Both feed and stripping solution are stirred with Teflon stirrers coupled with electric motors connected to a power supply. After the stirrers switch on, samples from feed and stripping solutions are taken at regular time intervals and analyzed in an atomic absorption spectrophotometer (VARIAN SpectrAA-880) in order to find the amount of remaining and transported silver ions. For the flux determination $\left(\mathrm{mol}_{\mathrm{Ag}} \mathrm{cm}^{-2} \mathrm{~s}^{-1}\right)$, the slope of the straight line resulting from the plot of feed or strip phase concentration ( $\mathrm{mol}_{\mathrm{Ag}} \mathrm{L}^{-1}$ ) versus time (s) is calculated. Later, the slope was multiplied by the volume phase $(\mathrm{L})$ and divided by the ACM exposed area $\left(\mathrm{cm}^{2}\right)($ see $(1))[28,29]$ :

$$
\text { Silver flux }=\frac{d C_{\mathrm{Ag}}}{d t} \cdot \frac{V_{\text {phase }}}{A_{\text {membrane }}} \text {. }
$$

\section{Results and Discussion}

3.1. Study of the Composition of the Receptor Solution for Silver Transport through ACM. In order to promote the transport of silver from the feed to the stripping phase, it was necessary to carry out the process shown in Figure 1.

According to Figure 1, the transport of silver will take place if the Ag is removed from the ACM by a means of regenerating the carrier agent, which possess acidic properties [30]. This can be achieved using an acid stripping solution that may also contain a complexing reagent; both protons and complexing reagent will have a synergistic effect that can release and remove the silver to the receiving phase.

Thus, the first study consisted of choosing an extracting agent using the information available on agents commonly employed for the reextraction of silver to the stripping solution. Five chemical conditions are shown in Table 1. This table also shows the logarithmic values of the conditional equilibrium constant for global formation at working conditions (when the driving force of the reextraction step is the formation of a complex).

The results showed that only thiourea is strong enough to break the DTPA-Ag complex and this is facilitated with the carrier regeneration (the replacement of $\mathrm{Ag}$ by $\mathrm{H}$ ) due to sulfuric acid. For this reason, the composition thiourea/sulfuric acid was used for subsequent studies, but optimizing the concentration of thiourea and studying the effect on the reextraction still need to be completed.

Table 2 shows the flows obtained for the extraction of silver from the membrane to the stripping phase containing 
TABLE 1: Values of global equilibrium constants $\beta_{n}^{\tau}$ for silver complexation under different stripping conditions $[20]$.

\begin{tabular}{lccc}
\hline $\begin{array}{l}\text { Stripping solution } \\
\text { constituent }^{\mathrm{a}}\end{array}$ & $\begin{array}{c}\text { Silver } \\
\text { complex }\end{array}$ & $\log \beta_{n}^{\tau}$ & $\begin{array}{c}\text { Presence of Ag in the } \\
\text { stripping solution }\end{array}$ \\
\hline $\mathrm{NH}_{3}$ & $\mathrm{Ag}\left(\mathrm{NH}_{3}\right)^{2+}$ & 7.22 & - \\
$\mathrm{EDTA}^{\mathrm{b}}(\mathrm{Y})$ & $\mathrm{AgY}^{3-}$ & 5.84 & - \\
$\mathrm{HNO}_{3}$ & - & - & - \\
$\mathrm{NaSCN}^{2-}$ & $\mathrm{Ag}(\mathrm{SCN})_{4}{ }^{3-}$ & 10.00 & - \\
tu & $\mathrm{Ag}(\mathrm{tu})_{3}{ }^{2-}$ & 13.41 & + \\
\hline
\end{tabular}

${ }^{\mathrm{a}}$ Chemical conditions: $\mathrm{NH}_{3}=$ ammonia buffer $\left(\mathrm{NH}_{4}{ }^{+} / \mathrm{NH}_{3} 0.5 \mathrm{~mol} \mathrm{~L}^{-1}\right)$, pH 9.4; EDTA $(\mathrm{Y})=$ ethylenediaminetetraacetic acid $0.1 \mathrm{~mol} \mathrm{~L}^{-1}$ in tris (tris(hydroxymethyl)aminomethane), $0.1 \mathrm{~mol} \mathrm{~L}^{-1} \mathrm{pH} 9.6 ; \mathrm{HNO}_{3} 2 \mathrm{~mol} \mathrm{~L}^{-1}$; NaSCN $0.5 \mathrm{~mol} \mathrm{~L}^{-1}$; tu = thiourea $0.3 \mathrm{~mol} \mathrm{~L}^{-1}$ in sulfuric acid $2 \mathrm{~mol} \mathrm{~L}^{-1}$.

${ }^{b}$ It was considered positive when its concentration in the receiving phase after three hours of experimentation was higher than the detection limit $\left(2.40 \times 10^{-7} \mathrm{~mol} \mathrm{~L}^{-1}\right)$.

TABLE 2: Silver flux from ACM to stripping phase according the thiourea concentration. ACM prepared with DTPA $0.75 \mathrm{~mol} \mathrm{~L}^{-1}$. Feed phase with Ag $4.64 \times 10^{-4} \mathrm{~mol} \mathrm{~L}^{-1}$ in $\mathrm{HNO}_{3} 0.1 \mathrm{~mol} \mathrm{~L}^{-1}$.

\begin{tabular}{lc}
\hline $\begin{array}{l}\text { Thiourea in stripping solution } \\
\left(\mathrm{mol} \mathrm{L}^{-1} \text { in } \mathrm{H}_{2} \mathrm{SO}_{4} 2 \mathrm{~mol} \mathrm{~L}^{-1}\right)\end{array}$ & $\begin{array}{c}\mathrm{Ag} \text { flux } \\
\left(\times 10^{-6} \mathrm{~mol} \mathrm{~cm}^{-2} \mathrm{~s}^{-1}\right)\end{array}$ \\
\hline 0.0 & $\mathrm{NO}^{\mathrm{a}}$ \\
0.1 & $\mathrm{NO}^{\mathrm{b}}$ \\
0.3 & $0.37(5.71)$ \\
0.6 & $0.58(11.4)$ \\
1.0 & $1.1(1.98)$ \\
\hline
\end{tabular}

Percentage of standard deviation in parenthesis. ${ }^{a} \mathrm{NO}=$ not observed. LOD $<1.65 \times 10^{-7} \mathrm{~mol} \mathrm{~L}^{-1} ;{ }^{\mathrm{b}} \mathrm{NO}=$ Not observed. LOD $<2.40 \times 10^{-7} \mathrm{~mol} \mathrm{~L}^{-1}$.

a solution of $2 \mathrm{~mol} \mathrm{~L}^{-1}$ sulfuric acid and different concentrations of thiourea. Although the increase of thiourea concentration improves the silver transport, the inconvenience of determining silver in a highly concentrated salt solution forced us to use the nearest previous concentration $\left(0.6 \mathrm{~mol} \mathrm{~L}^{-1}\right)$ for subsequent experiments.

According to these results, it was also possible to confirm that replacing the acidic protons of the carrier is not enough to free silver from the membrane, which indicates the strength of the DTPA-Ag complex [20, 30, 31].

\subsection{Variation of the Extraction and Reextraction Flux with} regard to the DTPA Contents of the ACM. After selecting the composition of the receiving phase, the study of the variation in the composition of the ACM was performed. Thus, several membranes were prepared from solutions having different DTPA concentrations. The resulting membranes were used to study the transport of silver. Results are shown in Figure 2. According to this, it may be seen that the silver flux is closely related to the DTPA content in the membrane and, depending on the application, a high-DTPA ACM may be chosen if the purpose of the experiment is to recover silver from an aqueous solution. By contrast, if the goal is silver transport or silver preconcentration, the best option is to reduce the DTPA concentration to allow an easy Ag release from the membrane, resulting in the uphill transport

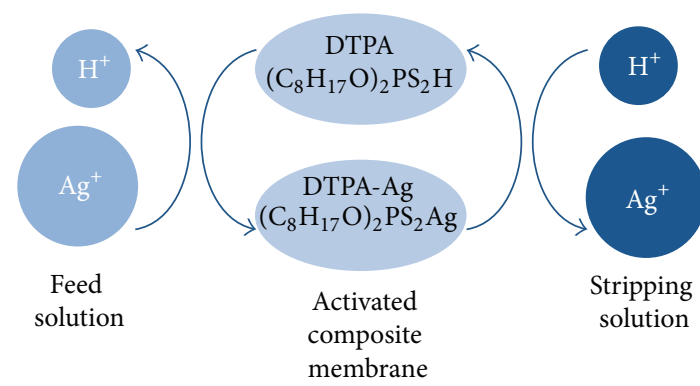

FIGURE 1: Silver transport mechanism from a feed to the stripping solution through an activated composite membrane with DTPA as the carrier agent.

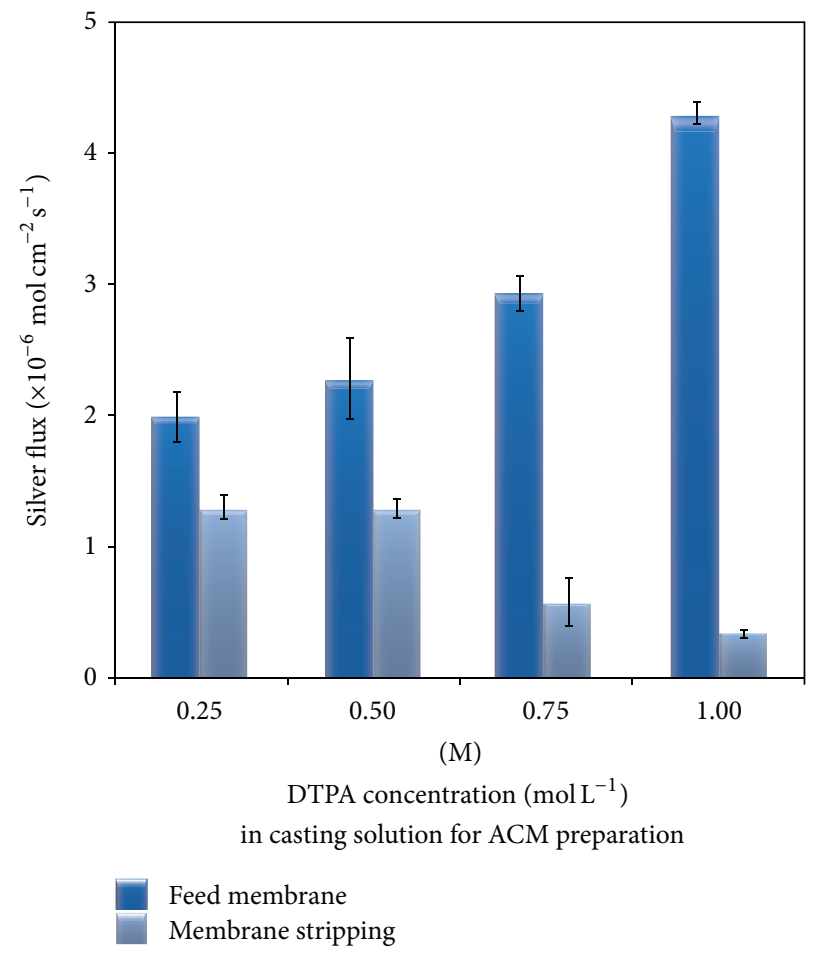

FIGURE 2: Variation of silver flux in a transport experiment using an ACM with different DTPA content. Feed phase with Ag $4.64 \times$ $10^{-4} \mathrm{~mol} \mathrm{~L}^{-1}$ in $\mathrm{HNO}_{3} 0.1 \mathrm{~mol} \mathrm{~L}^{-1}$; stripping phase with thiourea $0.6 \mathrm{~mol} \mathrm{~L}^{-1}$ in sulfuric acid $2 \mathrm{~mol} \mathrm{~L}^{-1}$. Bars represent standard deviation.

phenomenon. This is best illustrated in Figure 3 which shows that increasing the concentration of DTPA in the membrane causes a considerable increase of silver extraction (ca 94\%) but only $18 \%$ of the initial silver is transported. Conversely, if the content of DTPA in the ACM decreases, the percent of extraction decreased to $75 \%$, but the reextraction is facilitated obtaining $54 \%$ of silver transported. It should be noted that in the absence of DTPA, silver did not suffer any variation in feed phase and was undetectable in the stripping phase. 


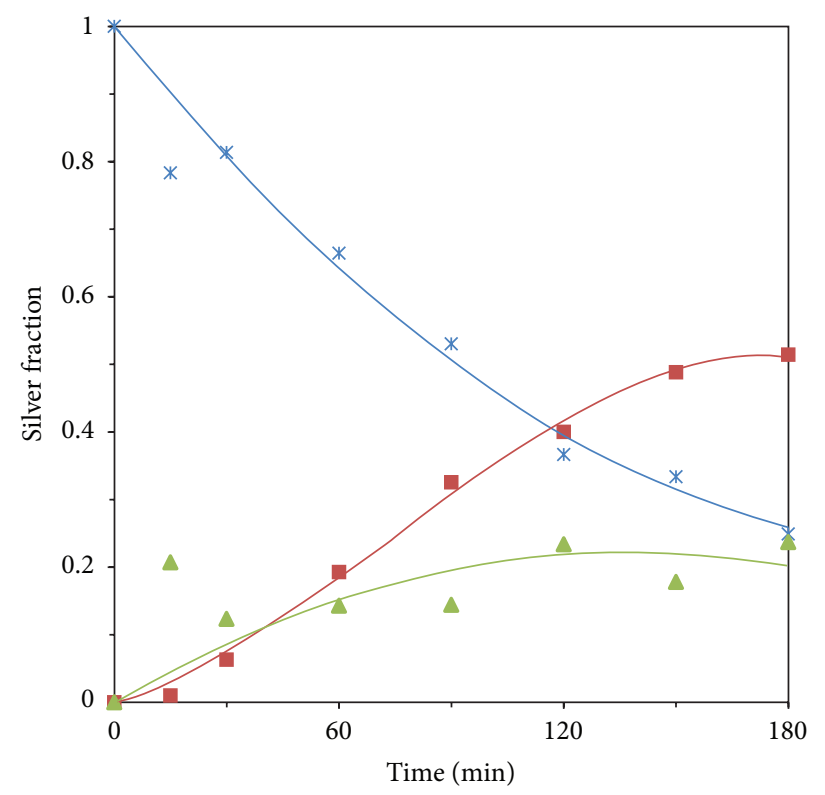

* Feed solution
Stripping solution
Activated composite membrane

(a)

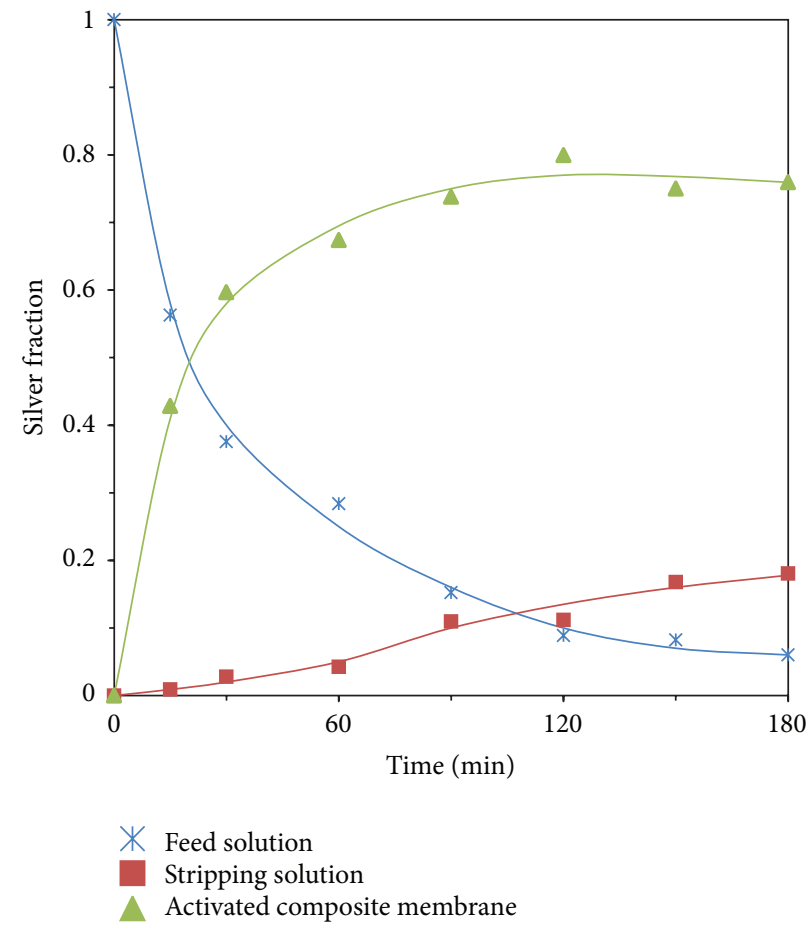

(b)

FIGURE 3: Silver fraction in different phases as function of time during a transport experiment through an ACM prepared with (a) DTPA $0.25 \mathrm{~mol} \mathrm{~L}^{-1}$ and (b) DTPA $1.00 \mathrm{~mol} \mathrm{~L}^{-1}$. Feed phase with $\mathrm{Ag} 4.64 \times 10^{-4} \mathrm{~mol} \mathrm{~L}^{-1}$ in $\mathrm{HNO}_{3} 0.1 \mathrm{~mol} \mathrm{~L}^{-1}$; stripping phase with thiourea $0.6 \mathrm{~mol} \mathrm{~L}^{-1}$ in sulfuric acid $2 \mathrm{~mol} \mathrm{~L}^{-1}$.

\section{Conclusions}

From this study, a new feasible alternative process for silver recovery is proposed. Under the best extraction conditions, the removed silver is higher than $94 \%$, while using a suitable DTPA content in the ACM, 54\% of the initial silver is transported to the stripping phase.

Although it is true that the transport results are not so high compared with some reports from the literature, with this study it is possible to foresee the use of ACM for the extraction of silver from complex solutions due to the great affinity of Ag to DTPA.

Furthermore, considering the results obtained for the transport of silver and similar metal ions such as mercury $[21,30,31]$, a possible alternative for separation may arise if a low concentrated thiourea stripping solution allows for the reextraction of $\mathrm{Hg}$ but does not favor silver.

\section{Conflict of Interests}

The authors declare that there is no conflict of interests regarding the publication of this paper.

\section{Acknowledgments}

Ma. Elena Páez-Hernández acknowledges CONACyT (200662581 Project) and PROMEP (SEP, Mexico) for the financial support. Yucundo Mendoza-Tolentino is grateful for his postgraduate studies grant. Ma. Elena Páez-Hernández, Carlos
Andrés Galán-Vidal, Giaan Arturo Álvarez-Romero, and M. T. Ramírez-Silva gratefully thank the SNI for the distinction of their membership.

\section{References}

[1] National Research Council, Separation Technologies for the Industries of the Future, The National Academies Press, Washington, DC, USA, 1998.

[2] R. W. Baker, Membrane Technology and Applications, John Wiley \& Sons, West Sussex, UK, 2nd edition, 2004.

[3] P. J. Pickering and C. R. Southern, "Clean-up to chirality Liquid membranes as a facilitating technology?" Journal of Chemical Technology and Biotechnology, vol. 68, no. 4, pp. 417424, 1997.

[4] J. de Gyves and E. R. de San Miguel, "Metal ion separations by supported liquid membranes," Industrial and Engineering Chemistry Research, vol. 38, no. 6, pp. 2182-2202, 1999.

[5] R. A. Kumbasar, "Selective separation of chromium (VI) from acidic solutions containing various metal ions through emulsion liquid membrane using trioctylamine as extractant," Separation and Purification Technology, vol. 64, no. 1, pp. 56-62, 2008.

[6] K. K. Bhatluri, M. S. Manna, P. Saha, and A. K. Ghoshal, "Supported liquid membrane-based simultaneous separation of cadmium and lead from wastewater," Journal of Membrane Science, vol. 459, pp. 256-263, 2014.

[7] Z. Ren, W. Zhang, H. Meng, J. Liu, and S. Wang, "Extraction separation of $\mathrm{Cu}(\mathrm{II})$ and $\mathrm{Co}(\mathrm{II})$ from sulfuric solutions by 
hollow fiber renewal liquid membrane," Journal of Membrane Science, vol. 365, no. 1-2, pp. 260-268, 2010.

[8] A. P. de Los Ríos, F. J. Hernández-Fernández, L. J. Lozano et al., "On the selective separation of metal ions from hydrochloride aqueous solution by pertraction through supported ionic liquid membranes," Journal of Membrane Science, vol. 444, pp. 469481, 2013.

[9] A. M. Neplenbroek, D. Bargeman, and C. A. Smolders, "Supported liquid membranes: instability effects," Journal of Membrane Science, vol. 67, no. 2-3, pp. 121-132, 1992.

[10] A. M. Neplenbroek, D. Bargeman, and C. A. Smolders, "Mechanism of supported liquid membrane degradation: emulsion formation," Journal of Membrane Science, vol. 67, no. 2-3, pp. 133-148, 1992.

[11] X. J. Yang, A. G. Fane, and K. Soldenhoff, "Comparison of liquid membrane processes for metal separations: permeability, stability, and selectivity," Industrial and Engineering Chemistry Research, vol. 42, no. 2, pp. 392-403, 2003.

[12] H.-D. Zheng, B.-Y. Wang, Y.-X. Wu, and Q.-L. Ren, "Instability mechanisms of supported liquid membranes for copper (II) ion extraction," Colloids and Surfaces A: Physicochemical and Engineering Aspects, vol. 351, no. 1-3, pp. 38-45, 2009.

[13] A. P. de los Ríos, F. J. Hernández-Fernández, F. Tomás-Alonso, J. M. Palacios, and G. Víllora, "Stability studies of supported liquid membranes based on ionic liquids: effect of surrounding phase nature," Desalination, vol. 245, no. 1-3, pp. 776-782, 2009.

[14] M. Resina, C. Fontàs, C. Palet, and M. Muñoz, "Comparative study of hybrid and activated composite membranes containing Aliquat 336 for the transport of Pt(IV)," Journal of Membrane Science, vol. 311, no. 1-2, pp. 235-242, 2008.

[15] M. J. Ariza, P. Prádanos, R. Rico, E. Rodríguez-Castellón, and J. Benavente, "X-ray action on polymeric membrane surfaces: a chemical and morphological characterization," Surface and Interface Analysis, vol. 35, no. 4, pp. 360-368, 2003.

[16] N. M. Kocherginsky, Q. Yang, and L. Seelam, "Recent advances in supported liquid membrane technology," Separation and Purification Technology, vol. 53, no. 2, pp. 171-177, 2007.

[17] T. He, "Towards stabilization of supported liquid membranes: preparation and characterization of polysulfone support and sulfonated poly (ether ether ketone) coated composite hollow fiber membranes," Desalination, vol. 225, no. 1-3, pp. 82-94, 2008.

[18] O. Villamo, C. Barboiu, M. Barboiu, W. Yau-Chun-Wan, and N. Hovnanian, "Hybrid organic-inorganic membranes containing a fixed thio ether complexing agent for the facilitated transport of silver versus copper ions," Journal of Membrane Science, vol. 204, no. 1-2, pp. 97-110, 2002.

[19] O. Arous, H. Kerdjoudj, and P. Seta, "Comparison of carrierfacilitated silver (i) and copper (ii) ions transport mechanisms in a supported liquid membrane and in a plasticized cellulose triacetate membrane," Journal of Membrane Science, vol. 241, no. 2, pp. 177-185, 2004.

[20] IUPAC Stability Constants Database from Academic Sotware, Academic Software, Yorks, UK, 1999.

[21] M. E. Páez-Hernández, K. Aguilar-Arteaga, M. Valiente, M. T. Ramírez-Silva, M. Romero-Romo, and M. Palomar-Pardavé, "Facilitated transport of $\mathrm{Hg}(\mathrm{II})$ through novel activated composite membranes," Analytical and Bioanalytical Chemistry, vol. 380, no. 4, pp. 690-697, 2004.

[22] M. E. Páez-Hernández, K. Aguilar-Arteaga, C. A. Galán-Vidal, M. Palomar-Pardavé, M. Romero-Romo, and M. T. RamírezSilva, "Mercury ions removal from aqueous solution using an activated composite membrane," Environmental Science and Technology, vol. 39, no. 19, pp. 7667-7670, 2005.

[23] G. E. Diet, ASM Handbook: Materials Selection and Design, vol. 20, ASM International, Cleveland, Ohio, USA, 1st edition, 1997.

[24] J. N. Parker and P. M. Parker, Allergies-A Medical Dictionary, Bibliography, and Annotated Research Guide to Internet References Paperback, Icon Health Publications, San Diego, Calif, USA, 2003.

[25] Committee on Bioavailability of Contaminants in Soils and Sediments, Bioavailability of Contaminants in Soils and Sediments: Processes, Tools, and Applications, The National Academies Press, Washington, DC, USA, 2003.

[26] C. Palet, M. Muñoz, S. Daunert, L. G. Bachas, and M. Valiente, "Vitamin B12 derivatives as anion carriers in transport through supported liquid membranes and correlation with their behavior in ion-selective electrodes," Analytical Chemistry, vol. 65, no. 11, pp. 1533-1536, 1993.

[27] M. Resina, J. Macanás, C. Fontàs, C. Palet, and M. Muñoz, "A comparative study of the selective transport of $\mathrm{Zn} / \mathrm{Cd}$ and $\mathrm{Pt} / \mathrm{Pd}$ couples with activated composite membranes and hybrid membranes," Desalination, vol. 240, no. 1-3, pp. 316-325, 2009.

[28] P. R. Danesi, "A simplified model for the coupled transport of metal ions through hollow-fiber supported liquid membranes," Journal of Membrane Science, vol. 20, no. 3, pp. 231-248, 1984.

[29] A. Kaya, H. K. Alpoguz, and A. Yilmaz, "Application of Cr(VI) transport through the polymer inclusion membrane with a new synthesized calix[4]arene derivative," Industrial and Engineering Chemistry Research, vol. 52, no. 15, pp. 5428-5436, 2013.

[30] L. Bromberg, I. Lewin, H. Gottlieb, and A. Warshawsky, "Interaction of mercury(II) and silver(I) with bis[di(2ethylhexyloxy)thiophosphoryl]disulfide," Inorganica Chimica Acta, vol. 197, no. 1, pp. 95-99, 1992.

[31] I. P. Alimarin, T. V. Rodionova, and V. M. Ivanov, "Extraction with thio and dithio phosphorus acids," Russian Chemical Reviews, vol. 58, no. 9, pp. 863-878, 1989. 

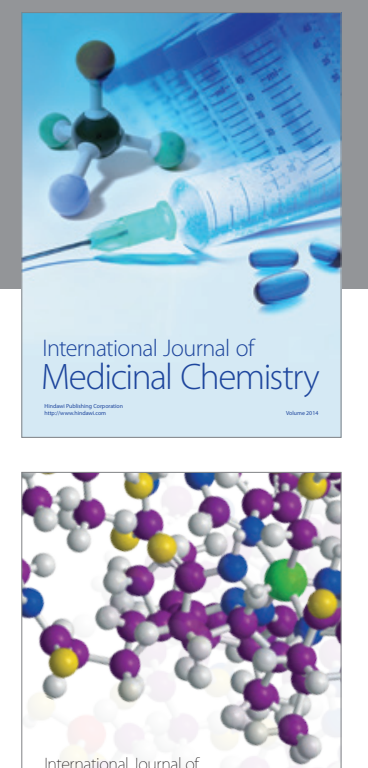

\section{Carbohydrate} Chemistry

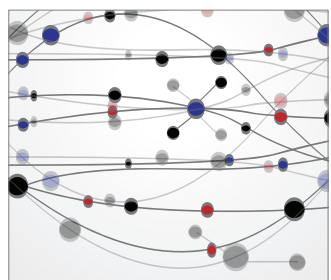

The Scientific World Journal
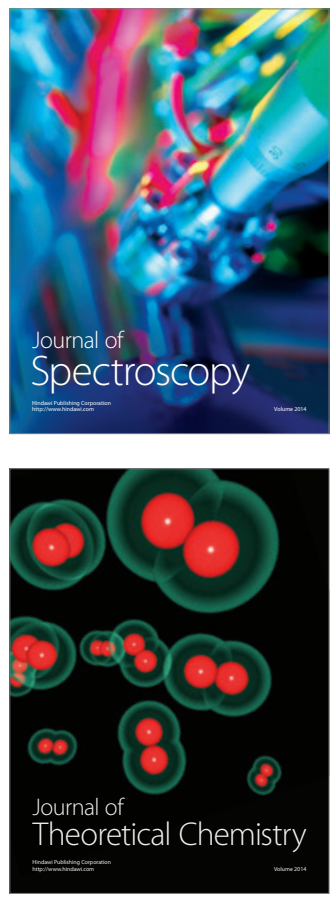
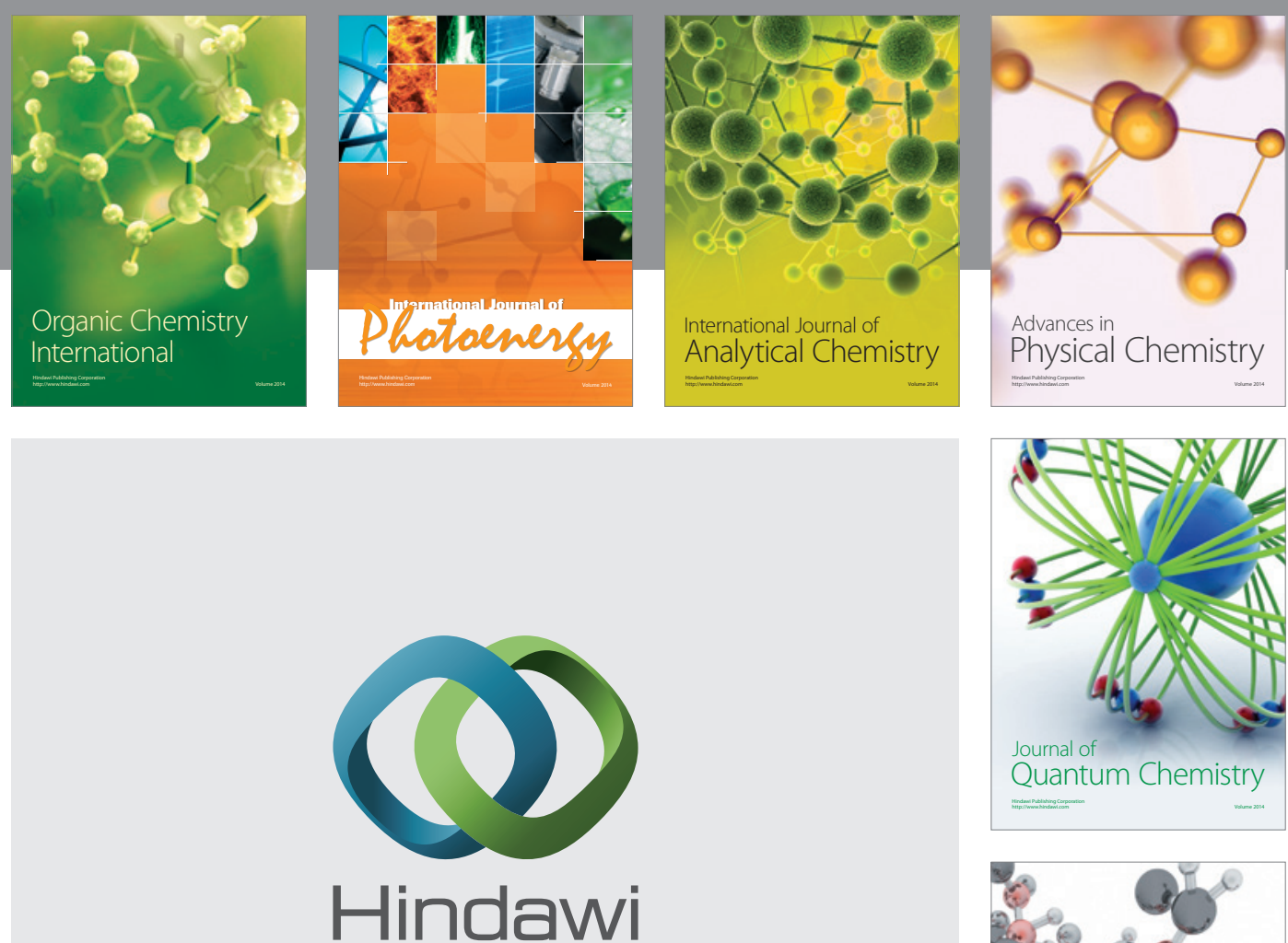

Submit your manuscripts at

http://www.hindawi.com

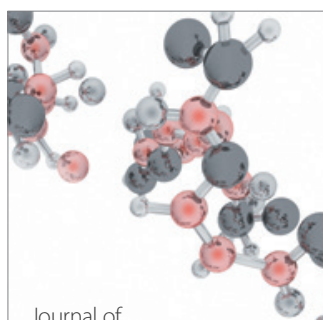

Analytical Methods

in Chemistry

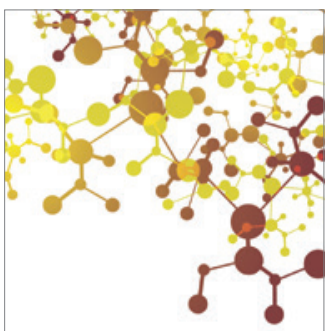

Journal of

Applied Chemistry

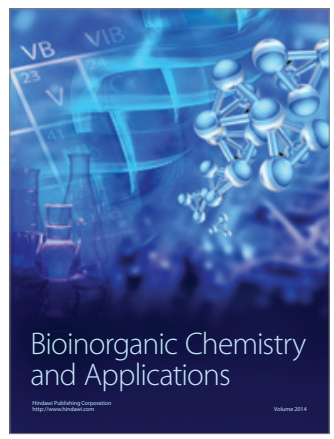

Inorganic Chemistry
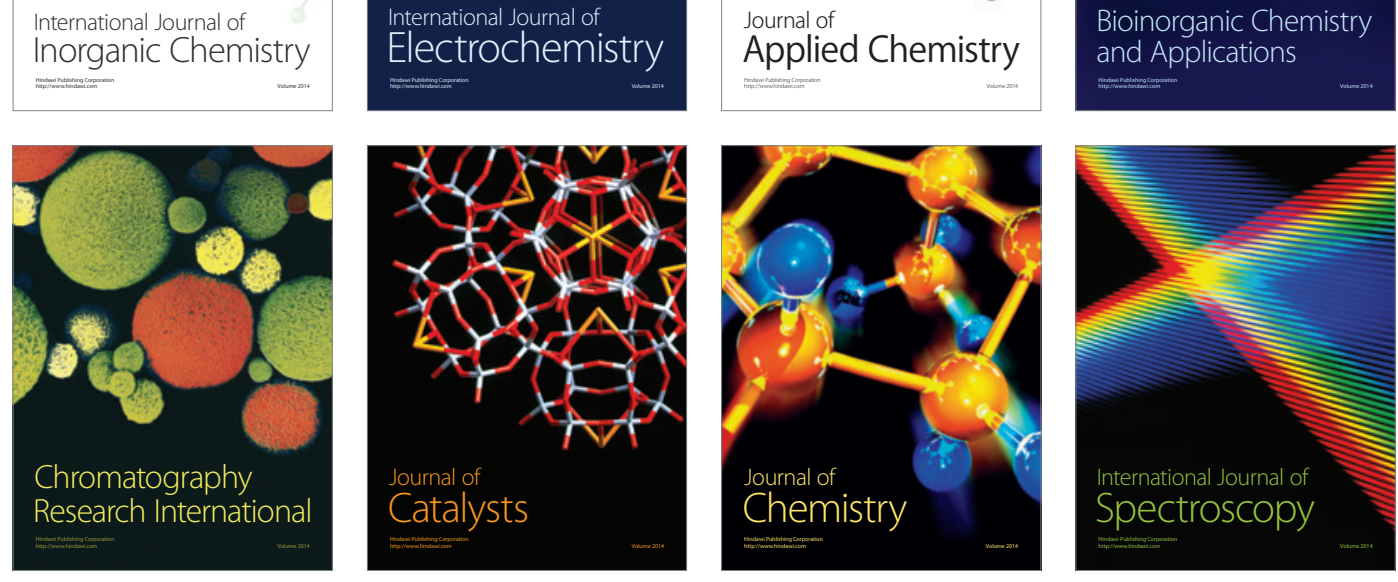